For citation please use CYELP, volume 1. More information available at www.cyelp.com

\title{
BALANCING SOVEREIGNTY WITH THE FREE MOVEMENT OF GOODS IN THE EU AND THE WTO \\ - Non-Pecuniary Restrictions on the Free Movement of Goods -
}

\author{
Tamara Perišin*
}

Summary: In every system that strives to achieve free trade, it is necessary to balance this aim with the protection of other values. Such balancing not only has strong implications for competitiveness and economic results, but also goes to the very heart of national regulatory autonomy, constitutionalism and sovereignty. The author first discusses the way in which this issue has been dealt with in the EU in the context of Article 28 EC, and explains how the ECJ has been changing the scope of the Article as well as extending the list of possible justifications for national measures caught by it. The paper then turns to an analysis of comparable issues in the WTO. Emphasis is given to the problems of comparing these two organisations, their mutual influences and convergence. Finally, the author discusses possible approaches and tests which could accommodate free trade as well as the protection of other values.

\section{INTRODUCTION}

In every system that strives to achieve free trade, it is necessary to balance this aim with the protection of other values. Such balancing not only has strong implications for competitiveness and economic results, but also goes to the very heart of national regulatory autonomy, constitutionalism ${ }^{1}$ and sovereignty.

In the European Union (EU), difficulties in striking the appropriate balance between the interests of the internal market, on the one hand, and national regulatory autonomy, on the other, have been most visible in the context of Article 28 EC. ${ }^{2}$ For decades the European Court of Justice (ECJ) has been trying to determine the precise scope of this Article. Its task has in no way been simple, especially since the many factual and legal circumstances in which the Article functions are constantly changing, so that what was perhaps a good point of balance in the 1970s can no longer be accepted. Thus, in its constant search for an appropriate balance, the ECJ has been broadening and narrowing the scope of Article 28, as well as extending the list of possible justifications for national measures caught by the Article. Finding an approach that would suit the

\footnotetext{
Tamara Perišin, MJur (Oxon), Department for European Public Law, Faculty of Law, University of Zagreb. I owe thanks to Professors Derrick Wyatt, Tamara Ćapeta and Siniša Rodin for their comments on earlier drafts, and to those who provided feedback when parts of this paper were presented at the Asser College Europe, T.M.C. Asser Institute in The Hague, and at the $3^{\text {rd }}$ Jean Monnet Module "Advanced Issues of European Law" in Dubrovnik.

${ }^{1}$ See M. Poiares Maduro, The Constitution of the Global Market, in F. Snyder (ed.), Regional And Global Regulation of International Trade, Hart Publishing, Oxford, 2002.

${ }^{2}$ Treaty Establishing the European Community, hereinafter EC, (Nice consolidated version) OJ 2002 C325/189
} 
current needs of trade, but which would also accommodate certain national choices, is important with regard to legal certainty and the coherence of case law. This is becoming even more significant as the ECJ seems to be forming a uniform approach towards indistinctly applicable measures in the area of the movement of goods, services, establishment and workers. ${ }^{3}$

The Court's approach to indistinctly applicable measures in the area of goods can be systematised into three stages, which will be further elaborated below, ${ }^{4}$ but the main argument in this paper will concern what the Court's approach should be. The approach which I support, and which could prevail in all the fundamental freedoms since it is strongly advocated in legal theory and its elements may already be observed in some judgements by the ECJ and opinions of the Advocates General, is a test with two criteria: the dual burden criterion (or indirect discrimination) and the criterion of market access. Regarding the latter criterion, it would have to be determined how serious an obstacle to market access must be in order to be regarded as contravening the Treaty. Namely, should only measures that completely bar market access be prohibited, or should less serious impediments also be considered breaches of Article 28?

In searching for an adequate solution, I consider it useful to look at the way the issue has been handled in other comparable systems, primarily the World Trade Organisation (WTO). The WTO is relevant not only because its provisions on the free movement of goods (FMG) can be compared to those in the EU, but also because the EU is a member of the WTO. WTO law is a part of the EC legal order, and is hierarchically superior to EC secondary legislation. ${ }^{5}$ Consequently, "the interlocking systems of trade law can have a profound effect on many of the most cherished foundations of European constitutionalism", and one cannot read cases concerning the EU's internal market critically "without a firm grasp of the GATT". ${ }^{6}$ Also, one must recognise that the two systems have begun to converge and, even though it is not clear to what extent further convergence is possible, it is certain that each of them can learn from the other's experience. Namely, the WTO, which is now moving beyond the requirement of discrimination in the free movement of goods, can draw many lessons from the ECJ's case law following Dassonville, while, at the same time, the ECJ, which is still searching for an optimal approach to indistinctly applicable measures, seems to be drawing closer to the national treatment principle of the GATT. Finally, a comparison of the EU and the WTO with regard to the free movement of goods could provide guidance concerning the effect which the EU's participation in the WTO might have on the latter's trade

\footnotetext{
${ }^{3}$ C-55/94 Gebhard v Consiglio dell'Ordine degli Avvocati e Procuratori di Milano [1995] ECR I-4165

${ }^{4}$ J. H. H. Weiler distinguishes 5 stages. J. H. H. Weiler, Epilogue: Towards a Common Law of International Trade, in J. H. H. Weiler (ed.), The EU, the WTO, and the NAFTA - Towards a Common Law of International Trade?, Oxford University Press, Oxford, 2000.

${ }^{5}$ C-61/94, Germany v. Commission, [1996] ECR I-3989. For a detailed analysis of the relationship between WTO law and the EC legal order, see F. Snyder, The Gatekeepers: The European Courts and WTO Law, CLMRev. 40, 2003, p. 313-367

${ }^{6}$ J. H. H. Weiler, Cain and Abel - Convergence and Divergence in International Trade Law, in THE EU, THE WTO, AND THE NAFTA, (n. 4), p. 3
} 
liberalisation and regulatory values ${ }^{7}$ (which have been particularly controversial in the environmental sphere).

\section{Introductory remarks on comparing the WTO and the EU}

When comparing the rules on free movement of goods in the EU and the WTO, one should not lose sight of the fact that these two systems have a different purpose, that they are composed of quite different constituencies, and that they have undergone different developments.

The goals of the EU were from the outset (i.e. from the EC) far more ambitious than those of the GATT. For while the goal of the GATT was to liberalise trade in goods, trade liberalisation in the EU was followed by a far-reaching programme of market integration and harmonisation, not just in the area of goods but also in services, establishment, workers and capital, all leading to the establishment of a single market and, later, even to the creation of a monetary union. European law represents a new legal order. ${ }^{8}$ The integration process in Europe includes political and constitutional integration, and has always been accompanied by broader considerations. In the beginning, this was primarily a desire to secure peace, ${ }^{9}$ and, furthermore, even the original Treaty contained several social provisions. Nowadays, the EU aims to be a "social market economy", ${ }^{10}$ and its human side is reflected in its protection of human rights, in the social, cultural, environmental and other values it supports, and in European citizenship.

Even though the "world trade system" cannot approach the level of integration achieved in the EU, the two systems became more similar when the World Trade Organisation was established following the Uruguay round of negotiations. The first reason for this was that the WTO's new mechanism of settling disputes changed "the rules and the legal culture concerning the adjudication and enforcement of obligations". ${ }^{11}$ Secondly, the world trade system has moved beyond mere liberalisation of trade in goods, such that the WTO now also covers agreements on services and intellectual property. Finally, there has been great change in the rules governing the free movement of goods. This last point will be further analysed below.

\section{World trade v. regional trade}

\footnotetext{
${ }^{7}$ S. Dillon, International Trade and Economic Law and the European Union, Hart Publishing, Oxford, 2002, p. $2 / 3$.

${ }^{8}$ The idea that WTO law should have a direct effect was rejected during the Uruguay round, while the fact that it does not have such an effect was confirmed by the Panel in United States - Sections 301-310 of the Trade Act of 1974, WT/DS152/R para. 7.72. For more on this, see F. Snyder, (n. 5).

${ }^{9}$ Dillon, (n. 7), p. 21.

${ }^{10}$ Art. I-3 of the Treaty Establishing a Constitution for Europe, OJ C 310/11 and Final Report of Working Group XI on Social Europe, CONV 516/1/03, REV 1, 4 February 2003.

${ }^{11}$ Weiler, (n. 4), p. 3.
} 
The GATT system and the WTO have economic advantages deriving from the fact that they contribute to worldwide trade liberalisation, which can only be achieved through subsequent rounds of multilateral negotiation. Namely, multilateral negotiations are an optimal way of tackling the problem of the prisoners' dilemma, which otherwise prevents states from unilaterally liberalising trade. ${ }^{12}$ However, the extent of possible integration within the WTO is limited by the number and diversity of its members, and this is the reason for deeper integration within regional trading blocs.

Regional trading blocs (RTBs) present an exception to the GATT principle of most-favoured nation status, which is permissible under the conditions set forth in Article XXIV. RTBs, in the form of either a free-trade area or a customs union, enable better allocation of resources within the bloc, and allow other common goals of its members to be achieved. It is often stressed that regional blocs necessarily create disadvantages for other parties to the GATT, because they lead to trade diversion "in the sense that lowercost producers outside the regional trading blocs are discriminated against". This consequently causes less efficient global allocation of resources and reduces global welfare. ${ }^{13}$ However, many argue that this has been overstated, and that extra-regional trade remains important for all regions. ${ }^{14}$

The question one might ask is why all countries do not enter into these tighter forms of integration, as well as why all regional trading blocs are not integrated as tightly as the EU, as this would benefit them economically? Trebilcock and Howse argue that tighter integration requires either centralised policy-making institutions or a hegemonic state, and that each of these options amounts to a certain loss of sovereignty, which most states are not ready to accept. ${ }^{15}$ The situation in Europe was specific, and it was easier for EU Member States to accept competences being conferred upon a central institution because the EU was, and remains, relatively homogeneous. To a certain extent, its Member States share a common history and common values, and there were no insurmountable differences in terms of their economic strength.

\section{Scope of this paper}

For the purposes of this paper, national measures affecting imports will be divided into two categories, i.e. those of pecuniary and those of non-pecuniary nature. The following analysis will focus on non-pecuniary measures, i.e. quantitative restrictions and measures having an equivalent effect, whereas pecuniary measures such as customs and taxes will not be discussed in detail.

In the EU, quantitative restrictions on imports of goods are regulated by Articles 28 and 30 - the former prohibits quantitative restrictions and measures of equivalent effect, while the latter provides exceptions to this general rule. As is well known, the ECJ

${ }^{12}$ M.J. Trebilcock and R. Howse, The Regulation of International Trade, $2^{\text {nd }}$ edition, Routledge, London New York, 2001, p. 7/8, 130.

${ }^{13}$ Ibid.

${ }^{14}$ Ibid., p. 131.

${ }^{15}$ Ibid., p. 129, 133. 
extended the list of possible justifications beyond Art. 30, introducing mandatory requirements ${ }^{16}$ which Member States can invoke in order to save their indistinctly applicable measures. The case law on the scope of Art. 28, on the one hand, and that on the scope of Art. 30 and permissible mandatory requirements, on the other, are interconnected, and can best be understood as parts of a single whole. However, for the purpose of more detailed academic analysis, it will be useful to address them separately.

This paper will deal only with the scope of Article 28, which is an issue logically prior to the list of exceptions to Art. 28. Namely, it is first necessary to establish the rule, i.e. what type of national measures fall within the scope of Article 28, and only then can one go into the exceptions to this rule, i.e. justifications. Unfortunately, there is still no certainty in the EU concerning what exactly this rule is (though a number of scholars have proposed what it should be). Thus, determining the rule before going any further in its analysis is the correct methodology. ${ }^{17}$ Moreover, this issue can be of great practical significance in determining the outcome of litigation ${ }^{18}$ and delimiting the workload for national judges deciding concrete cases. Their task will be much clearer if they can rely on a well-defined scope of Art. 28 and know which measures are not caught by it, rather than having to search for a justification that would be applicable in a given case. This is especially true since the list of mandatory requirements is not exhaustive. Consequently, I believe that a clear and precise definition of the scope of Art. 28 is of crucial importance in allowing national courts to act as European courts. Without it, domestic judges will not be able to correctly decide free movement of goods cases on their own, but will have to refer a large number of cases to the ECJ.

The present analysis of WTO rules is restricted to those which are comparable with Art. $28 \mathrm{EC}$ and to the most relevant developments in this respect.

\section{NON-PECUNIARY RESTRICTION ON FREE MOVEMENT OF GOODS IN THE EU}

Article 28 EC provides that quantitative restrictions on goods imports and all measures having an equivalent effect are prohibited. This broad definition has left the Court considerable leeway in its interpretation. ${ }^{19}$ While it was clear from the outset that discriminatory measures were caught by the Article, the ECJ also placed indistinctly

\footnotetext{
${ }^{16}$ 120/78 Rewe-Zentrale AG v Bundesmonopolverwaltung für Branntwein [1979] ECR 649

${ }^{17}$ Weiler, (n. 4), p. 225.

${ }^{18}$ Since, for example, a ban on Sunday trading could be allowed as falling outside the scope of the Article; however, if it were to fall within its scope, then it might or might not be justified.

${ }^{19}$ The Commission gave its standpoint on measures having an equivalent effect to quantitative restrictions in its Directive 70/50 [1970] OJ L13/29. According to Article 2 of the Directive, it covers distinctly applicable measures which hinder imports, while Article 3 prescribes that it "also covers measures governing the marketing of products... which are equally applicable to domestic and imported products, where the restrictive effect of such measures on the free movement of goods exceeds the effects intrinsic to trade rules". However, an argument can be derived from the Preamble to the effect that Article 3 may be intended to cover only indirectly discriminatory measures ("Whereas such is the case where imports are either precluded or made more difficult or costly than the disposal of domestic production"). D. A. Wyatt and A. A. Dashwood, European Union Law, $4^{\text {th }}$ ed., Sweet and Maxwell, London, 2000, p. 321.
} 
applicable measures within its scope. ${ }^{20}$ Since then, the main issue has been how to create adequate and reasonable limits to challenging indistinctly applicable measures, i.e. to determine which types of such measures should fall outside the scope of Article 28.

The Court's approach towards indistinctly applicable measures may be viewed over three stages. In the first stage, Article 28 was considered to cover discriminatory national measures; in the second stage, the Court declared that the Article also covered indistinctly applicable measures; while the third stage of development was significant for creating limits on challenging indistinctly applicable national measures (Keck and Krantz line of case law). In each phase, the ECJ tried to rectify the drawbacks of its previous approach. Therefore, insight into this entire development is indispensable for understanding the issues involved and determining what the optimal approach would be.

\section{Bringing non-discriminatory measures within the scope of Article 28}

Already in the 1970 s it had become clear that the mere requirement of nondiscrimination would not do much to aid the functioning of the internal market, since many non-discriminatory measures could also present serious obstacles to intraCommunity trade. The groundbreaking case that brought indistinctly applicable measures within the scope of Article 28 was Dassonville. ${ }^{21}$ Although the measure at stake in Dassonville could be regarded as discriminatory to channels of trade, the Court decided to take a more active role in facilitating the internal market, and created a broader interpretation of Article 28 that placed all indistinctly applicable measures within its scope. Namely, the Court gave an explanation of the concept of "measures having an effect equivalent to quantitative restrictions", stating that these were "all trading rules enacted by a Member State which were capable of hindering, directly or indirectly, actually or potentially, intra-Community trade". ${ }^{22}$

J. H. H. Weiler argues that Dassonville was "heroic" because it was the first case that went beyond the conventional conservative view of a liberal trade regime. Namely, the conventional view differentiates between rules on market access and rules on market regulation, arguing that the former should be obstacle-based, while the latter require only non-discrimination. In contrast, Dassonville created an obstacle-based rule in the area of market regulation. This is the reason why Dassonville is regarded as having gone farther than Statistical Levy ${ }^{23}$, its counterpart in the pecuniary area, which remained within the conventional theory by setting an obstacle-based rule in the area of market access. Weiler further points out that the Dassonville approach had a logical basis in the Treaty itself -

\footnotetext{
${ }^{20}$ The term "distinctly applicable measure" is used in this paper to describe a measure that is applied differently to goods, persons, services or capital depending on their Member State of origin, thus amounting to discrimination. Indistinctly applicable measures in their face do not prescribe differential treatment, but they may impose either an additional or an equal burden. In the former case, their effect is discriminatory (indirect discrimination) even though there need be no discriminatory or protectionist motive, while in the latter case such measures can be regarded as non-discriminatory.

${ }^{21}$ 8/74 Procureur du Roi v Dassonville [1974] ECR 837.

${ }^{22}$ Ibid. para. 5.

${ }^{23}$ 24/68, Commission v. Italy, [1969], ECR 193
} 
while in the pecuniary area the Treaty differentiated between pecuniary measures affecting market access (customs, Art. 25) and those concerning market regulation (taxes, Art. 90), it did not make such a distinction in the non-pecuniary area. Thus, when Dassonville applied an obstacle-based approach to both market access and market regulation, conflating the two, it did not go beyond the Treaty (Table 1). ${ }^{24}$

Table 1 - EC Articles on free movement of goods and their scope

\begin{tabular}{|c|c|c|}
\hline & pecuniary area & non-pecuniary area \\
\hline MARKET ACCESS & $\begin{array}{l}\text { Art. } 25 \text { EC } \\
\text { - all obstacles }\end{array}$ & $\begin{array}{c}\text { Art. } 28 \mathrm{EC} \\
\text { - all obstacles (Dassonville), }\end{array}$ \\
\hline MARKET REGULATION & $\begin{array}{c}\text { Art. } 90 \text { EC } \\
\text { - only discriminatory measures }\end{array}$ & $\begin{array}{l}\text { except for those types excluded } \\
\text { by the Keck and Krantz line of } \\
\text { case law (see below) }\end{array}$ \\
\hline
\end{tabular}

The effect and implications of the reasoning in Dassonville only became clear following Cassis de Dijon. ${ }^{25}$ In Cassis the ECJ began by saying that, in the absence of common rules, Member States were free to regulate, and held that "obstacles to movement within the Community resulting from disparities between national laws relating to the marketing of the products in question must be accepted in so far as those provisions may be recognized as being necessary in order to satisfy mandatory requirements". ${ }^{26}$ This is the core of the principle of mutual recognition (or "functional parallelism", as Weiler calls $i^{27}$ ), which guarantees that a product lawfully produced and marketed in one Member State can be introduced into any other Member State.

Cassis represented an important step forward from Dassonville, because its principle of mutual recognition shifted the burden of proof to the traders' advantage. Namely, if traders could not import products lawfully produced and marketed in one Member State to another Member State, the onus was no longer on them to prove that the measure in question was a restriction in the meaning of Article 28. On the contrary, it was on the Member State of destination to prove that the restriction was justified. This was a "radical shift of emphasis in favour of free trade", ${ }^{28}$ without which there would be serious disturbances in the internal market. Namely, products from a Member State with less regulated production and marketing would have been disabled from entering the market of a Member State with a higher level of regulation, while products from the latter could more easily enter the former's market. Consequently, Member States would find themselves in a race to regulate in order to provide competitive advantages for their producers. Furthermore, even if Member States were equally regulated quantitatively, free movement would be prevented if those regulations were not qualitatively identical. ${ }^{29}$

\footnotetext{
${ }^{24}$ Weiler, (n. 4), p. 205-07.

${ }^{25}$ (n. 16)

${ }^{26}$ Ibid., para. 8

${ }^{27}$ Weiler, (n. 4), p. 219.

${ }^{28}$ However, the Cassis reasoning was not a novelty, especially when bearing in mind Directive 70/50. S.

Weatherill and P. Beaumont, EU Law, $3^{\text {rd }}$ ed., Penguin Books, London, 1999, p. 568/69.

${ }^{29}$ Wyatt and Dashwood, (n. 19), p. 324.
} 
Cassis also went further than Dassonville in another important respect, that is, by introducing the concept of mandatory requirements. Namely, the ECJ was relatively sensitive in balancing states' interests in protecting certain values with the interests of market integration, and saw that it would be unreasonable to treat indistinctly applicable measures and discriminatory measures alike. Therefore, it held that the former could be justified not only by the derogations listed in Art. 30 EC, but also by other mandatory requirements. One could say that, in this way, Cassis actually narrowed the Dassonville formula.

It is interesting that the Court was able to decide in Cassis without addressing the whole problem of indistinctly applicable measures. Namely, the basis for its judgement could have been the fact that a national rule imposed a dual burden on imported products, since these had already complied with the requirements of their state of origin. In other words, the Court could have argued that the national provision de facto indirectly discriminated against importers. However, the ECJ went the other way, covering all indistinctly applicable measures by means of Article 28.

Although the Court's case law on the reasons for prohibiting indistinctly applicable measures is not yet fully settled or clear, it is worthwhile to examine some of the reasons that can be observed in cases following Cassis. For example, in Oosthoek's, ${ }^{30}$ which concerned a Dutch law that restricted the offering or giving of products as free gifts within the framework of a commercial activity, the Court gave two reasons for reviewing indistinctly applicable measures regulating marketing methods. The first was that the producer in the case could have been compelled to "adopt advertising or sales promotion schemes which differ from one Member State to another", ${ }^{31}$ resulting in an additional burden on him. The second reason was that he could have been forced to discontinue a scheme that he considered particularly effective (see below in connection to Douwe Egberts.

\section{Limits to challenging non-discriminatory measures}

Soon after the Cassis judgement, it became clear that there should be limits to the Court's control over indistinctly applicable measures. First of all, a flood of cases began to overburden the Court, and there was also serious criticism of, and resistance to, the possibility that the ECJ might analyse each and every national measure that in some way impeded intra-Community trade, e.g. rules prohibiting fire-arms. ${ }^{32}$ The difference between indistinctly applicable measures in these cases and in Cassis-type ones was that, in the former, there existed an equal burden on the marketing of domestic and foreign products, while the latter imposed a dual burden (and indirectly had a discriminatory effect).

\footnotetext{
${ }^{30}$ 286/81 Oosthoek's Uitgeversmaatschappij BV [1982] ECR 4575

${ }^{31}$ Ibid. para. 15.

${ }^{32}$ Weatherill and Beaumont, (n. 28), p. 608.
} 
Case law tried to "save" measures imposing an equal burden in three ways. Firstly, it began to extend the list of objective justifications for all indistinctly applicable measures; secondly, it excluded some measures from the scope of Article 28 because their effect on the free movement of goods was "too uncertain and indirect"; and, finally, in Keck $^{33}$ the Court withdrew a whole category of measures from the scope of the Article. These three methods of saving indistinctly applicable measures will be analyzed in the following paragraphs.

As far as the first method of limiting Art. 28, i.e. justifying non-discriminatory and other indistinctly applicable measures, it was noted above that Cassis introduced other justifications additional to the ones set forth in Article 30. The list of these mandatory requirements was not exhaustive, and the Court has extended it on many occasions. For example, in Cineteque ${ }^{34}$ it identified the protection or enhancement of a work of art as a possible objective justification for a law banning the sale or hire of videos of films during the first year after their release, while in Torfaen ${ }^{35}$ the Court added protection of national and regional socio-cultural characteristics to the list of mandatory requirements.

The cornerstone case for the second method of limiting the scope of Article 28 was Krantz, where the Court stated that the possibility that nationals of other Member States might hesitate to sell goods on instalment to purchasers in the Netherlands (because those goods could be seized by the tax collector if the purchasers failed to discharge their tax debts) was "too uncertain and indirect to warrant the conclusion that a national provision authorizing such seizure is liable to hinder trade between Member States". ${ }^{36}$ It is important to note that Krantz and other cases which adopted this line of reasoning did not concern "certain selling arrangements" in the sense of the Keck judgement. ${ }^{37}$ Thus they saved measures which Keck could not withdraw from the scope of Art. 28. Therefore, the ECJ continued to use the formula "too uncertain and indirect" even after Keck, as a way of correcting the inadequacies in its Keck jurisprudence; moreover, it applied this approach to other areas of free movement (e.g. establishment in Semeraro, ${ }^{38}$ or workers in $\mathrm{Graf}^{39}$ ). I consider the Krantz line of case law extremely important for finding an optimal approach to Article 28, due to the fact that it entails a balancing test (based on proportionality and de minimis assessments, as analysed infra in chapter IV). ${ }^{40}$

${ }^{33}$ C-267-8/91 Criminal proceedings against Keck and Mithouard [1993] ECR I-6097

${ }^{34}$ 60/61-84 Cinetheque SA v Federation Nationale des Cinemas Francais [1985] ECR 2605

${ }^{35} 145 / 88$ Torfaen BC $v B$ \& $Q$ plc [1989] ECR 3851

${ }^{36}$ C-69/88 H Krantz GmbH \& Co. v Ontvanger der Directe Belastingen and Netherlands State [1990] ECR I-0583, para 11

${ }^{37}$ C. Barnard, Fitting the Remaining Pieces into the Goods and Persons Jigsaw (2001) 26 ELRev. 35

${ }^{38}$ C-418/93 Semeraro Casa Uno Srl v Sindaco del Commune di Erbusco, joined cases, etc. [1996] ECR I2975

${ }^{39}$ C-190/98 Volker Graf v Filzmoser Maschinenbau GmbH [2000] ECR I-493

${ }^{40}$ This appears contrary to the ECJ's rejection of the de minimis rule in the context of Art. 28 in joined cases 177 and 178/82, Criminal Proceedings against Van de Haar and Kaveka de Meern BV, [1984] ECR 1797 
The third way of limiting the scope of Article 28, as developed in Keck, has had the greatest significance so far. In that case, which concerned a French law prohibiting resale at a loss, the Court began its reasoning by recalling Cassis and restating that Article 28 includes "obstacles to the free movement of goods where they are the consequence of applying rules that lay down requirements to be met by such goods... even if those rules apply without distinction to all products". ${ }^{41}$ It then continued to develop a new formula, stating that "contrary to what has previously been decided, the application to the products from other Member States of national provisions restricting or prohibiting certain selling arrangements is not such as to hinder directly or indirectly, actually or potentially, trade between Member States within the meaning of the Dassonville judgement". ${ }^{42}$

The Court did not explain why there was insufficient impact on intra-Community trade; ${ }^{43}$ it merely stated that this depends upon two conditions. The first was that the "provisions apply to all affected traders operating within the national territory", while the second was "that they affect in the same manner, in law and in fact, the marketing of domestic products and of those from other Member States". ${ }^{44}$ These two conditions were of key importance because, should they be fulfilled, a rule on selling arrangements would not by nature be such as to prevent access to the market of products from other Member States, nor to impede their access more than that of domestic products (para 17).

Keck's contribution to limiting the scope of Article 28 was that it kept the rules on product requirements (Cassis-type) within the Article, in that they imposed a dual burden, while at the same time withdrawing from the catch of the Article rules on "certain selling arrangements" which presented an equal burden, and which neither prevented market access to products from other Member States, nor impeded their access more than that of domestic products. The difference between the two categories of indistinctly applicable measures distinguished in Keck was also reflected in the burden of proof. In the case of rules on product requirements that are always within the scope of Article 28, the onus of proving that the rules are justified under Article 30 or under mandatory requirements is on the Member State. In contrast, in the case of certain selling arrangements, it is primarily up to the party challenging the rule to prove that it discriminates or affects market access in a prohibitive manner, so as to bring it under Article 28. If this is successful, the onus probandi then moves to the Member State, which must prove that the rule is justified, as in the former case. ${ }^{45}$

\footnotetext{
${ }^{41}$ Keck, (n. 33), para. 15 .

42 Ibid. para. 16. It is interesting that the Court began the key part of its judgement with "contrary to what has previously been decided", and did not refer to the concrete case law it was overruling. These were, surely, the Sunday Trading cases (inter alia Torfaen, supra), but it is possible that there were disagreements within the Court itself on the extent of the case law which was supposed to be overruled, such that the issue was not explicitly addressed in the judgement.

${ }^{43}$ L.W. Gormley, Reasoning Renounced? The Remarkable Judgement, in Keck \& Mithouard, 1994 , Euro. Bus. L. Rev. 63.

${ }^{44}$ Keck, (n. 33), para. 16.

${ }^{45}$ See Barnard, (n. 37), p. 45.
} 
Unfortunately, Keck left many unclarified issues, one of the most important of which was the meaning of selling arrangements, as these could often be very difficult to distinguish from product requirements. As Craig and de Búrca point out, it is possible to distinguish between static and dynamic selling arrangements. ${ }^{46}$ While the former, e.g. rules relating to the opening hours of shops, do not truly impose any additional burden on the movement of products from other Member States, the latter, e.g. advertising rules, can have such an effect. Subsequently, rules on dynamic selling arrangements do not meet the second condition from Keck, and thus return within the scope of Article 28. This problem will be discussed further in relation to post-Keck advertising cases (inter alia, De Agostini $^{47}$ and Gourmet International ${ }^{48}$ ).

Weiler argues that the formulation "certain selling arrangements" is inadequate, and that the Court's intent must have been to exclude from the reach of Art. 28 measures which may restrict the volume of sales, and hence the volume of sales of products from other Member States, yet without barring their access to the market and discriminating against them. He points out that there is no reason to distinguish certain selling arrangements from other measures that meet this test, because their effect is the same (e.g. a ban on selling cigarettes in machines, which is a rule on certain selling arrangements, can have the same effect as a ban on smoking in public places). ${ }^{49}$

Finally, it is worth commenting on the reasons that influenced the Court in reaching such a judgement in Keck. The first reason, which was even mentioned by the Court itself in its judgement, was the flood of cases that had begun to burden it. It stated that, in view of the increasing tendency by traders to invoke Article $30^{50}$ as a means of challenging any rules whose effect was to limit their commercial freedom, even where such rules were not aimed at products from other Member States, the Court considered it necessary to re-examine and clarify its case law on this matter. ${ }^{51}$ However, as Weiler notes, if a doctrine is justified on its merits, then one tries to deal with the phenomena that gave rise to the increase in case load, rather than change the doctrine. Therefore, it is easy to agree that the ECJ's change of approach was a necessary consequence of the changes that had occurred since Dassonville, i.e. in the socio-political and economic reality in which that doctrine was rooted. ${ }^{52}$

It should also be noted that the load of case law reaching the ECJ carried with it a threat to the Court's legitimacy. Namely, in deciding such cases the Court would become involved in judging as to the reasonableness of various market regulations, which were often based on economic analyses that the Court could and should not reassess.

\footnotetext{
${ }^{46}$ P. Craig and G. de Búrca, EU Law - Texts, Cases and Materials, $3^{\text {rd }}$ ed., Oxford University Press, Oxford, 2002), p 649.

${ }^{47}$ C-34-36/95 KO v De Agostini (Svenska) Forlag AB \& TV-Shop i Sverige AB [1997] ECR I-3843

${ }^{48} \mathrm{C}-405 / 98 \mathrm{KO} v$ Gourmet International Products $A B$ [2001] ECR I-1795

${ }^{49}$ Weiler, (n. 4), p. 228.

${ }^{50}$ It is interesting how, from the wording of the judgement, it might seem that the Court found traders themselves responsible for this flood of cases.

${ }^{51}$ Keck (n. 33), para. 14.

${ }^{52}$ Weiler, (n. 4), p. 226.
} 
Furthermore, such regulations inevitably entailed a discretion in balancing public interests which should be left to the Member States. ${ }^{53}$

Another possible reason that has often been stressed in explaining Keck was the fact that the Single European Act (SEA) ${ }^{54}$ amended Article 100a EC (now 95), which prescribed the procedure for adopting measures on the approximation of provisions laid down by law, regulations, or administrative actions in Member States whose object was the establishment and functioning of the internal market. ${ }^{55}$ After SEA, Article 100a no longer required unanimity within the Council, but rather a qualified majority. Consequently, Community legislative action became easier, and there was no further need for the Court to have extensive control over non-discriminatory measures. This seems even more probable when one bears in mind that, in Cassis, the Court began to assume judicial control over indistinctly applicable measures, having first emphasised that there were no common rules in the problem area.

The ECJ may have passed this area into the hands of legislators, but it also narrowed the leeway for Community regulations. After Keck, measures which had been caught by Art. 28 but were justified ceased to be within the reach of Community legislators. This "more limited form of Community governance" was "very much in the Geist of the times". ${ }^{56}$

Regardless of what the Court's original intentions were, that is, even if it initially gave up its control over "certain selling arrangements" because Community legislative action under Article 95 had become easier, there can be no doubt that it subsequently took the direction of disabling specific legislation under Article 95 in this area. Namely, in the Tobacco Advertising judgement, ${ }^{57}$ the ECJ called into question the Community's competence to harmonise "certain selling arrangements" under Article 95. The Court held that Article 95 did not give the Community legislature a general power to regulate, but that any measure adopted thereunder must genuinely have as its object the improvement of conditions for the establishment and functioning of the internal market. Any such measure would have to aim at preventing obstacles to trade.

In the case of "certain selling arrangements", it could be argued that they did not pose obstacles to trade, and that this was exactly the ECJ's reason for excluding them from the scope of Article 28. Under this presumption, "certain selling arrangements" could not be regulated under Article 95, as their harmonisation would not prevent any obstacles to trade.

However, the Court did not say anything of the sort. The ECJ did not reveal whether Article 95 had the same scope regarding the free movement of goods as Article 28 , so that it would be applicable only to barriers to trade caught by the latter. While this

${ }_{53}$ M. P. Maduro, Harmony and Dissonance in Free Movement in M. Andenas and W. H. Roth (eds) Services and Free Movement in EU Law, Oxford University Press, Oxford, 2002

${ }^{54}$ Single European Act, OJ L 169 29. 6. 1987.

${ }^{55}$ S. Weatherill, After Keck: Some Thoughts on How to Clarify the Clarification, (1996) 33 CMLRev. 886.

${ }^{56}$ Weiler, (n. 4), p. 228.

${ }^{57}$ C-376/98 Germany v European Parliament \& Council [2000] ECR I-8419 
remains to be resolved in future cases, in my opinion Art. 95 should be construed more broadly than Art. $28 .^{58}$

It is noteworthy that some rules on selling arrangements, which perhaps could not be harmonised as obstacles to the free movement of goods, can have a significant effect on the free movement of services or the freedom of establishment and, therefore, could be harmonised under Article 95 insofar as they create obstacles to the exercise of those freedoms (Gourmet, Pfeiffer). ${ }^{59}$

\section{Post-Keck advertising cases and other selling arrangements}

Following Keck, there have been many significant cases applying the concept of certain selling arrangements and giving it a clearer meaning. In these cases, the criterion of marketing, which was the second condition in Keck (para. 16), as well as the entire test of preventing market access or impeding it more for products from other Member States than for domestic products (Keck, para. 17), gained more importance.

Most of these cases arose in the area of national rules on advertising. Among the first was Hunermund, ${ }^{60}$ in which a national measure prohibited pharmacists from advertising quasi-pharmaceutical products outside a pharmacy. The Court treated this rule as falling within the category of indistinctly applicable measures on selling arrangements, but in deciding whether the rule was within the scope of Article 28 it did not fully examine the two conditions from Keck. That is, the ECJ did not truly assess the condition of marketing, wrongly linking its fulfilment to the fulfilment of the first condition of indistinct applicability. It stated that a rule "which applies without distinction as to the origin of the products in question to all pharmacists... does not affect the marketing of goods from other Member States differently from that of domestic products" ${ }^{61}$ Therefore, it concluded that Article 28 was not applicable to the rule in question.

This reasoning was repeated in Leclerc-Siplec, ${ }^{62}$ which dealt with a refusal to broadcast an advertisement on the distribution of fuel in Leclerc supermarkets, on the grounds that a decree excluded the distribution sector from televised advertising. The indistinctly applicable rule on selling arrangements was regarded as outside the scope of Article 28, because the Court declared that the two conditions from Keck had been

\footnotetext{
${ }^{58}$ Concerning the interconnection between Articles 28 and 95, the Court has more recently held that, while a measure adopted on the basis of Art. 95 constituted a measure equivalent to a quantitative restriction, it was nevertheless justified on grounds of the public health protection provided for in Art. 30. C-210/03, Swedish Match AB and Swedish Match UK Ltd v. Secretary of State for Health, judgement of 14 December 2004.

${ }^{59}$ Cf Gourmet (n. 48) and C-255/97 Pfeiffer Grosshandel GmbH v Lowa Warenhandel GmbH [1999] ECR $\mathrm{I}-2835$

${ }^{60}$ C-292/92 Hunermund v Landesapothekerkammer Baden-Wurttemberg [1993] ECR I-6787

${ }^{61}$ Ibid., para. 23.

${ }^{62}$ C-412/93 Societe d'Importation Edouard Leclerc-Siplec v TF1 Publicite SA and M6 Publicite SA [1995] ECR I-0179
} 
fulfilled. Once again, it did so without fully examining whether this was really true for the condition of marketing.

By way of contrast, in later cases the ECJ started to examine the conditions from Keck more thoroughly. De Agostini concerned a restriction on using certain marketing practices in television advertising for a children's magazine, skin-care products and a detergent. The Court first relied on Leclerc-Siplec, stating that the rule in question concerned selling arrangements. It then went on to discuss the conditions laid down in Keck, stating that while it was obvious that the first condition had been fulfilled (the rule applied to all traders operating within a national territory), it was not so obvious that the second condition had been, since "it cannot be excluded that an outright ban, applying in one Member State, of a type of promotion for a product which is lawfully sold there might have a greater impact on products from other Member States". ${ }^{63}$ Consequently, the Court recognised the possibility that advertising rules could fall within Article 28.

The Court went even further with this line of reasoning in Gourmet International, which concerned a restriction on the advertising of alcohol in magazines. The Court, having first established that the measure was indistinctly applicable to selling arrangements, examined whether the two conditions from Keck had been met. It concluded that the first had been met, i.e. the measure applied to all traders operating within a national territory, while the second condition had not been fulfilled, because "in the case of products like alcoholic beverages, the consumption of which is linked to traditional social practices and to local habits and customs", such a national measure "is liable to impede access to the market by products from other Member States more than it impedes access by domestic products, with which consumers are instantly more familiar". ${ }^{64}$ This case went further than De Agostini, because the Court did not just leave the national court with the option of deciding whether a rule on selling arrangements was within the scope of Article 28, but rather it explicitly stated that such a rule was caught by this Article.

In Douwe Egberts, ${ }^{65}$ Advocate General Geelhoed opined that a distinction should be made between the types of rules in De Agostini and Gourmet, on the one hand, and those in Hunermund and Leclerc, on the other. The first type of rules involve an outright prohibition, while the latter cover advertising prohibitions that are limited in scale, e.g. prohibitions on unsightly advertising, advertising on public buildings, and advertising certain products at certain events. He argued that the latter type of rules do not prevent access to the market or commercialisation by other means. These rules "do not seek to restrict access to the market and are further removed from marketing as such" ${ }^{6} 6$

However, the first problem in distinguishing between these two types of rules is that the test from para. 17 of Keck requires not only that a rule not prevent market access (which is true for Geelhoed's second category of rules), but also that it not impede market access more for imported products than for domestic products. It is not clear that the

${ }^{63}$ De Agostini, (n. 47), para. 42.

${ }^{64}$ Gourmet, (n. 48), para. 21.

${ }^{65}$ Opinion of Advocate General Geelhoed in C-239/02 Douwe Egberts, delivered on 11 December 2003.

${ }^{66}$ Ibid., para. 73. 
second type of rules would meet this condition. Another problem with the test is that, while a rule perhaps does not seek to restrict access to the market, it might still have such an effect (which is more relevant that the intention of the rule).

In Douwe Egberts, ${ }^{67}$ the Court followed the Advocate General in finding that national rules prohibiting the use of references to slimming and to medical recommendations and attestations in the advertising of foodstuffs was contrary to Art. 28. It did not address separately all the conditions from Keck, but rather it referred to its previous comparable case law. It repeated that compelling a producer to discontinue an advertising scheme which he considers particularly effective may constitute an obstacle to importers (Oosthoek's, supra), and that an absolute prohibition on advertising product characteristics impedes market access for products from other Member States more than for domestic products, with which consumers are more familiar (Gourmet, supra). Consequently, Community law would not allow the rules in question to be applied to imported products, while there was no such protection for domestic products.

It is important to stress that, in order for a measure to be considered discriminatory or protective, "it is not necessary for it to have the effect of favouring national products as a whole or of placing only imported products at a disadvantage and not national products". ${ }^{68}$ Thus it is irrelevant that the sale of products from other parts of a national territory is also affected. This was emphasised in Heimdienst, where a national rule limited sales on rounds by making them dependent on a permanent establishment in a specified district. This rule was indistinctly applicable and concerned selling arrangements, but it did not meet the second condition from Keck, i.e. it did not affect in the same manner the marketing of domestic products and that of products from other Member States. Similar reasoning was later applied in DocMorris. ${ }^{69}$

\section{NON-PECUNIARY RESTRICTIONS ON FREE MOVEMENT OF GOODS IN THE WTO}

There are two main provisions in the GATT whose function can be compared to that of Article 28 EC: namely, Article XI and Article III. Article XI proscribes prohibitions or restrictions on the importation and exportation (or sale for export) of goods between contracting parties, "other than duties, taxes or other charges, whether made effective through quotas, import or export licences or other measures". Article III interacts with Art. XI in that it requires like imported and domestic products to be treated equally or, in other words, forbids various national measures from being "applied to domestic and imported products so as to afford protection to domestic production".

An interpretative note to Article III serves to draw the line between Articles III and XI by providing that an internal tax or charge, or any law, regulation or requirement

${ }^{67}$ C-239/02 Douwe Egberts, judgement of 15 July 2004.

${ }^{68}$ C-254/98 Schutzverband gegen unlauteren Wettbewerb v TK-Heimdienst Sass GmbH [2000] ECR I-151, para. 27

${ }^{69}$ C-322/01, Deutscher Apothekverband eV v. 0800 DocMorris NV, Jacques Waterval, judgement of 11 December 2003, para 74. 
under Art. III (1) which applies to like imported and domestic products, is subject to the provisions of Art. III even when enforced, in the case of imported products, at the time or point of their importation. Therefore, a measure enforced at the time or point of importation should first be analysed under Article III and, should it be established that the measure does not fall within this Article, then it automatically falls within Art. XI (but may be justified under other GATT provisions). ${ }^{70}$

Similar to Art. 30 EC, Art. XX GATT provides an exhaustive list of justifications for national measures that are deemed contrary to other GATT provisions. This paper will consider below whether the WTO allows other justifications not explicitly mentioned in its agreements.

While for a long time the world trade system required only the non-discriminatory treatment of imported products, since the establishment of the WTO it seems that the system is moving towards an obstacle-based approach to the free movement of goods. As G. de Búrca notes, there are three elements whereby the free movement of goods has gone beyond pure non-discrimination. Firstly, the Agreement on Technical Barriers to Trade (hereinafter, TBTA or TBT Agreement) and the Agreement on the Application of Sanitary and Phytosanitary Measures (hereinafter, SPSA or SPS Agreement) prohibit certain forms of non-discriminatory barriers to trade, as can also be seen from the Beef Hormones case (below). Secondly, there is an "increasing subtlety" in determining "like products" under Article III, and it is on this basis that a measure which does not have a discriminatory purpose may be found in breach of the GATT. Finally, as the concept of discrimination has become more "complex, expansive and fluid", it cannot easily be used to restrict the scope of trade liberalisation. ${ }^{71}$ These issues will be analysed in the following chapters, albeit in reverse order.

\section{Complexity of the concept of discrimination}

One of the most striking pre-WTO cases in which we see how blurry the line is between the mere requirement of non-discrimination, on the one hand, and dealing with all obstacles to trade, on the other, is Tuna/Dolphin. The U.S. Marine Mammal Protection Act (MMPA) prescribed tuna harvesting in a specified "dolphin-friendly" manner, and prohibited the importation of tuna which was not harvested in the specified manner until the country of origin could prove that its programme of marine mammal protection and its average rate of the incidental taking of such mammals were comparable to those of the U.S.

\footnotetext{
${ }^{70}$ This sequence of application of Articles III and XI can be seen in the Tuna /Dolphin cases. United States Restrictions on Imports of Tuna 30 ILM (1992) 1598 (Tuna/Dolphin I) and 33 ILM 839 (1994) (Tuna/Dolphin II).

${ }^{71}$ De Búrca, Unpacking the Concept of Discrimination in EC and International Trade Law, in C. Barnard and J. Scott (eds), The Law of the Single European Market, Unpacking Premises, Hart Publishing, Oxford, 2002.

p. $190,195$.
} 
The Panel examined whether the MMPA could be categorised as an internal regulation covered by Art. III or a restriction under Art. XI: "The structure of the GATT is arguably such that measures which comply with Art. III are 'saved' and will not fall for consideration under the GATT Article XI prohibition of quantitative restrictions". ${ }^{72}$ In contrast, if a measure does not comply with Art. III, it is a restriction under Art. XI, and as such it has to be justified by one of the justifications listed in Art. XX.

The Panel noted that both Art. III:1 and Art. III:4, as well as the interpretative note to Art. III, refer only to "products", and that the rules of the MMPA could not be regarded as applying to tuna products as such. Consequently, the MMPA and measures on process or production methods in general were considered outside the scope of Art. III, and thus were caught by Art. XI. As a measure caught by Art. XI, the MMPA had to be justified by the derogations provided in Art. XX. However, the U.S. did not succeed in persuading the Panel, and the MMPA was found contrary to the GATT.

Concerning the concept of "like products", which is important for understanding how measures that many consider non-discriminatory can breach Art. III, the Panel stated that even if the MMPA were regarded as falling within Article III, the U.S. would still be in breach of Art III:4. Namely, it considered that "regulations governing the taking of dolphins incidental to the taking of tuna could not possibly affect tuna as a product", and so "dolphin-unfriendly" tuna was not a different product than dolphin-friendly tuna.

I disagree with the Panel, in respect of both its conclusion that Art. III does not cover PPMs and its test for determining whether products are like. While the issue of "like products" will be discussed in a separate chapter below, it should be noted here that the Panel drew its conclusion that Art. III does not cover PPMs based on the fact that the Article repeatedly refers to "products". However, as Howse and Regan emphasise, "the repeated reference to 'products' tells us nothing about the product/process distinction. It merely reflects that GATT is about trade in goods, not about trade in services or movement of capital or labour". ${ }^{73}$ Furthermore, if one were to accept that Article III does not cover process-based measures, this would have unacceptable consequences. For there are many process-based measures (e.g. process-based taxes) that would completely escape review under the GATT if they were not caught by Art. III, since they could not be subsumed under any other GATT provisions. ${ }^{74}$ Some consider that an interpretation of Art. III as covering PPMs would open the door too wide, since every kind of PPM, no matter how irrational or ridiculous, might be permitted. ${ }^{75}$ However, this argument becomes invalid if we accept the "aim and effects" test of determining likeness under Art. III (see below)._It is also worth emphasising here that "process or production method" (PPM) is now regulated by the TBT and SPS Agreement, and it will be discussed below,

\footnotetext{
${ }_{72}$ J. Scott, On Kith and Kine (and Crustaceans): Trade and Environment in the EU and the WTO, in THE EU, THE WTO AND THE NAFTA, (n. 4), p. 134.

${ }^{73}$ R. Howse, D. Regan, The Product/Process Distinction - An Illusory Basis for Disciplining "Unilateralism" in Trade Policy, EJIL, vol. 11, no. 2, 2000, p. 254.

${ }^{74}$ Ibid. E.g. process-based taxes which, unlike the measure at stake in Tuna/Dolphin, could not be considered quantitative restrictions.

${ }^{75}$ M. Matsushita, T. J. Schoenbaum, P. C. Mavroidis, The World Trade Organization - Law, Practice, and Policy, Oxford University Press, Oxford, 2003, p. 464.
} 
that the Appellate Body (AB) has developed tests for determining the "likeness" of products which go beyond their physical characteristics.

The Panel report in Tuna/Dolphin has never been adopted, as it was blocked by the U.S. Thus, a year after the report, the EC initiated new proceedings against the U.S., in which the Panel reached the same conclusions as in the previous case (Tuna/Dolphin II). A similar case appeared several years later, concerning a US law aimed at preventing the incidental capture and drowning of sea turtles by shrimp trawlers (Shrimp/Turtles). ${ }^{76}$ Once again, the Panel regarded the US measure as constituting a "prohibition or restriction" within the meaning of Art. XI, one not justified by Art. XX. ${ }^{77}$ These cases raised much concern about the balancing of trade liberalisation and regulatory standards for environmental and consumer protection. Many feared that trade liberalisation would "weaken both their own country's regulatory standards and those of their nation's trading partners". ${ }^{78}$ Namely, mutual challenges to environmental and other standards between contracting parties would represent a race to the bottom. It was becoming clear that there was a need for some sort of positive harmonisation that could balance the interests involved.

\section{Like products - difficulties in distinguishing discriminatory and non- discriminatory measures}

As was stated above, one of the means by which the WTO is moving beyond the requirement of non-discrimination towards an obstacle-based approach is its increasing subtlety in determining "like products" within the meaning of Art. III GATT. This issue is important, since Art. III prescribes that imported products must not be treated less favourably than like domestic products, while products which are not like may be treated differently.

This area of WTO law is still very unsettled, and there is great uncertainty for member states as they cannot be confident which types of national measures will be considered to be in breach of Art. III. The problem is that the Appellate Body has not created a general rule for determining likeness; rather, it considers the issue of whether products are like as one to be decided on a case-by-case basis, and regards the "like product" concept as similar to an accordion, stretching and contracting depending upon the particular legal or factual context in which the issue is being decided. ${ }^{79}$ Moreover, it regards such a decision as always involving the subjective discretion of the decision-

\footnotetext{
${ }^{76}$ United States - Import Prohibitions on Certain Shrimp and Shrimp Products, Report of the Panel, WT/DS58/R, 15 May 1998 and Report of the Appellate Body, WT/DS58/AB/R, 12 October 1998.

${ }^{77}$ The measure was found to constitute unjustifiable discrimination between countries where the same conditions prevail, and was thus contrary to the chapeau of Art. XX.

${ }^{78}$ Trebilcock and Howse, (n. 12), p. 136.

${ }^{79}$ Japan - Tax on Alcoholic Beverages, Report of the Appellate Body, WT/DS/8,10-11/AB/R, 4 October 1996, paras. 20-21.
} 
maker. ${ }^{80}$ Consequently, as Matsushita, Schoenbaum and Mavroidis point out, there are four tests for determining whether products are like. ${ }^{81}$

Firstly, with regard to the first sentence of Art. III:2, which prescribes that imported products shall not be subject to internal taxes and charges in excess of those applied to like domestic products (which is comparable to the provision of Art. 90(1) EC), the Appellate Body has adopted a "physical characteristics" test. Secondly, regarding the second sentence of Art. III:2, providing that no contracting party shall otherwise apply internal taxes and charges to imported or domestic products so as to afford protection to domestic production (which is comparable to Art. 90 (2) EC), an interpretative note provides that "like" in this context means "directly competitive and substitutable". The third test was applied by the AB in EC-Asbestos in the context of Art. III:4, which requires that laws, regulations and requirements affecting the internal sale, purchase, transportation or use of imported products must not be less favourable than those affecting domestic products. The Appellate Body stated that the determination of likeness under Art. III:4, as derived from Art. III:1, pertains to the nature and extent of the competitive relationship between and among products. The fourth test, which is strongly advocated in legal theory, is the "aim and effects" test that was developed in US - Malt Beverages and US - Taxes on Automobiles. This test takes into account the policy objective of Art. III:1, that is, it aims to determine whether there is a legitimate regulatory purpose in distinguishing between the products at stake, or whether the purpose of a measure is "to afford protection to domestic production" (aim). The test also looks at the market effects of the measure, i.e. whether its effect on the conditions of competition is protective.

\section{1. "Aim and effects" test}

Hudec argued that the "aim and effects" test, although not yet a finished legal standard, brings major improvements to the traditional tests under Article III. ${ }^{82}$ Namely, this test would narrow the scope of measures considered to breach Art. III GATT, in that the latter would catch only those measures with a protective aim or effect. Measures without a protectionist regulatory purpose (e.g. those on environmental or consumer protection) and without a protectionist effect would not be regarded as breaching Art. III. In other words, according to the "aim and effects" test for likeness, products should be considered "like" if they do not differ in any respect relevant to an actual nonprotectionist policy, and are not in a competitive relationship. ${ }^{83}$ Consequently, measures differentiating between products on the basis of a non-protectionist policy would be in accordance with the GATT.

In this way, the issue of regulatory justification can be examined at the same time as the issue of violation itself, in contrast to the traditional approach, which first

\footnotetext{
${ }^{80}$ Id. para. 22.

${ }^{81}$ Matsushita, Schoenbaum, Mavroidis, (n. 77)

${ }^{82}$ R. E. Hudec, GATT/WTO Constraints on National Regulation: Requiem for an "Aim and Effects" Test, International Lawyer, Fall 1998

${ }^{83}$ See Regan, Further Thoughts on the Role of Regulatory Purpose under Article III of the General Agreement on Tariffs and Trade, Journal of World Trade, 37 (4), 2003, p. 751
} 
determines that a measure violates Art. III, and then analyses whether it is justified under Art. XX. The "aim and effects" approach has opened the way for indistinctly applicable measures to be justified by any legitimate regulatory purpose, and not only by the exhaustive list in Art. XX. This improvement also has "the added advantage of bringing article III analysis in line with the analytic framework of the new Standards Code and SPS Code, both of which had adopted a one-stage test of violation where a question of justification is treated simultaneously with the issue of protective trade effects". ${ }^{84}$

However, there are problems in fitting the "aim and effects" test into the text of the GATT, especially with regard to the first sentence of Art. III.2. Namely, as the second sentence of Art. III.2 explicitly invokes the general policy of Art. III.1 that national measures should not be applied "so as to afford protection to domestic production" (aim), it is hard to argue that this same policy stands behind the first sentence. However, I contend that the whole of Art. III has the same general objective as stated in its paragraph 1 ; thus there is no obstacle to using the "aim and effects" test in the context of Art. III.2's first sentence.

The second argument against the "aim and effects" test is that it renders Art. XX redundant. ${ }^{85}$ I likewise disagree with this argument, for two reasons. Firstly, the "aim and effects" test of determining likeness under Art. III could be used to save only those national measures which do not have a protectionist aim and effect. It is difficult to be certain about this issue, as the "aim and effects" test is not a finished legal standard; however, there might be measures that it would not save. These measures could then be justified under Art. XX (if the discrimination caused were not arbitrary or unjustifiable, and if there would not be a disguised restriction on international trade). Secondly, Art. $\mathrm{XX}$ cannot become redundant, as it contains general exceptions. Therefore, it applies not only to measures contrary to Art. III, but also to all other provisions of the GATT.

It appeared that the Appellate Body had rejected the "aim and effects" test in Japan - Alcoholic Beverages. ${ }^{86}$ Here it was clear that the test was rejected in the context of the first sentence of Art. III:2. Regarding the second sentence of Art. III.2, the Appellate Body supported the test of "protective application", which can be considered to present an objective analysis of regulatory purpose, while rejecting the "aim" in the sense of the actual motivation of legislators and regulators. This rejection of "aim" as the actual subjective motivation of legislators was not quite clear, in that most commentators never understood the analysis of aim as going beyond an objective purpose. ${ }^{87}$

The Chile - Taxes on Alcoholic Beverages ${ }^{88}$ case can be seen as a reaffirmation of the "aim and effects" test, as it shed new light on Japan - Alcoholic Beverages. In Chile - Alcohol the Appellate Body stated that it called for examination of the design, architecture and structure of a tax measure precisely to permit identification of a measure's objectives and purposes. It noted that, in contrast to the subjective intention of

${ }^{84}$ Hudec, (n. 82), p. 628.

${ }^{85}$ On both arguments, see Hudec, (n. 82), p. 628/629

${ }^{86}$ n. 76

${ }^{87}$ See, inter alia, Hudec, Regan (n. 82, 83)

${ }^{88}$ Chile - Taxes on Alcoholic Beverages, WT/DS/87 and 110/AB/R, 12 January 2000 
legislators, "the purpose or objectives of a Member's legislature and government as a whole" are pertinent "to the extent that they are given objective expression in the statute itself" ${ }^{89}$ Consequently, following Chile - Alcohol it seems that the Appellate Body intends to continue developing the "aim and effects" test.

Regarding the use of the "aim and effects" test under Art. III:4, I agree with D. Regan, who says that Art. III:2 - first sentence, Art. III:2 - second sentence, and Art. III:4 "have the same general aim, specified in Article III:1, and they should all be interpreted in the same spirit". ${ }^{90}$ Consequently, I think that all of the aforementioned cases are also relevant in the context of Art. III:4. The AB dealt precisely with this provision of the GATT in EC-Bananas and, four years later, in EC-Asbestos. Contrary to what it held in the former case, in the latter it stated that interpretation of Art. III:4 required taking into account the policy of Art. III:1 that measures should not be applied "so as to afford protection to domestic production" (aim). ${ }^{91}$

It should be stressed that the "aim and effects" approach has important consequences for distinguishing between measures on products themselves and on the process or production method (PPM). As we saw above, PPMs were not regarded as falling within the scope of Art. III. However, as the Panel in Tuna/Dolphin noted, even if they were to do so, traditional tests for determining likeness would not permit differentiation between products based on their process or production method. Since many PPMs are not directly related to the characteristics of the product, ${ }^{92}$ it would be regarded that products distinguished on the basis of such PPMs are "like" and should be treated equally (i.e. it would not allow differentiation between dolphin-friendly and dolphin-unfriendly tuna). Consequently, many measures whose aim and effect were not protectionist would still be considered in breach of Art. III GATT. I consider this limitation of national regulatory autonomy in the WTO to be unnecessary.

A more balanced solution requires two steps. The first is to consider PPMs within the scope of Art. III, in accordance with the text of the GATT (supra) The second step would be to apply the "aim and effects" test, which would permit origin-neutral processbased measures. In other words, if a state differentiates between products on the basis of a PPM, and there is a legitimate (non-protectionist) purpose for such a differentiation, then such national measures would be in accordance with the GATT. On the contrary, measures that refer to PPMs but are "country-based" or protectionist in some other way would be prohibited. (An example of country-based PPM measures was that in Tuna/Dolphin prohibiting the importation of all tuna from a country which allowed dolphin-unfriendly fishing, instead of looking at the way in which certain tuna were actually caught.)

\footnotetext{
${ }^{89}$ Ibid, paras. 62,71

${ }^{90}$ D. Regan, (n. 83), p. 739.

91 European Communities - Regime for the Importation, Sale and Distribution of Bananas, WT/DS27/AB/R, 1997, para 216, European Communities - Measures Affecting Asbestos and AsbestosContaining Products, WT/DS135/AB/R, 2001, paras. 93, 98.

92 In contrast, there are also PPMs that are directly related to product characteristics (e.g. in Beef Hormones).
} 
To conclude this analysis of the concept of "like products", there are, as shown above, several tests for determining the "likeness" of products, and these differ with regard to the GATT provision at stake. As the Appellate Body determines this on a caseby-case basis, treating the concept of "like products" as an "accordion which stretches and squeezes", it also puts national regulatory autonomy in the role of an accordion. The "aim and effects" test, though not yet a finished legal standard, could solve this problem. This test would enable states to apply measures which do not have a protectionist regulatory purpose and effect in a way which they consider suitable. As these measures would not be in breach of Article III, there would be no need to justify them under limited grounds in Art. XX.

\section{Obstacle-based approach following the Uruguay round}

In the Uruguay round, two agreements were adopted to address the concern that trade liberalisation would lead to the race to the bottom: the TBT Agreement and the SPS Agreement. On the one hand, they stress the importance of national autonomy in adopting measures for the protection of life or health (and, in the TBT Agreement, certain other interests as well). On the other hand, the TBT and SPS Agreements also facilitate trade liberalisation, and aim at preventing all unnecessary obstacles to trade, which means that they go beyond the requirement of non-discrimination. As this type of deregulation could lead to a race to the bottom, these agreements aim to prevent this by encouraging the development of international standards. ${ }^{93}$ The TBTA and SPSA do not harmonise their respective areas, but they do encourage such harmonisation and mutual recognition.

\subsection{TBT Agreement}

The TBT Agreement provides that member states shall ensure that technical regulations are not prepared, adopted or applied with a view or effect of creating unnecessary obstacles to international trade, and, further, that technical regulations shall not be more trade-restrictive than necessary to fulfil a legitimate objective, taking into account the risks that non-fulfilment would create (Art. 2.2). ${ }^{94}$

It is clear from this Article that the TBTA covers not only measures discriminating against imports, but rather all types of obstacles to international trade. These obstacles can be justified by an open-ended list of "legitimate objectives", provided they have not been prepared, adopted or applied with a view (which, in my opinion, means "with an aim") or effect of creating unnecessary obstacles to international trade. The "aim and effects" test in the context of Art. III GATT is to be welcomed for bringing analysis of the GATT in line with this approach of the TBTA and SPSA.

\footnotetext{
${ }^{93}$ Preambles of Agreement on Technical Barriers to Trade and Agreement on the Application of Sanitary and Phytosanitary Measures

${ }^{94}$ Emphasis added.
} 
The question that arises is whether "legitimate objectives" under Art. 2.2 can be used to justify discriminatory measures. Although the solution in concrete cases might be the same, regardless of this issue, the question is important from a methodological point of view. Namely, if the answer were negative, then one would not have to continue deciding on a measure's justification and proportionality. The result in a concrete case might be the same since, even if we could use legitimate objectives to justify a discriminatory measure, the measure would still probably be considered to be in breach of the TBTA. That is, it could not be justified since it would fail the proportionality test: "not more trade-restrictive than necessary to fulfil a legitimate objective".

Art. 2.2 must be read together with Art. 2.1, which completely prohibits discriminatory measures. Consequently, such measures cannot be justified by the openended possibilities of justification under Art. 2.2. Moreover, the TBTA does not contain any provisions for their justification. Due to this, discriminatory technical regulations must be dealt with under GATT Art. III and XX (Reformulated Gasoline). ${ }^{95}$ -

Here we can note a parallel with the EU. It was stated above that, when rules on the free movement of goods in the EU went beyond the requirement of nondiscrimination to cover all obstacles to trade, the ECJ then realised that there must be the possibility of justifying such measures by interests other than those set forth in Art. 30 EC. It created an open-ended list of mandatory requirements. Similarly, "legitimate objectives" and "regulatory purpose and effect other than those of creating unnecessary obstacles to trade" in the TBT Agreement go further than Art. XX GATT. ${ }^{96}$ In both systems, discriminatory measures can still be justified only by means of an exhaustive list of justifications (Art. 30 EC, Art. XX GATT), although it is noteworthy that many have argued against this solution (e.g. Advocate General Jacobs in PreussenElektra, ${ }^{97}$ Craig and de Búrca ${ }^{98}$ ). The difference in approach between the TBTA and the EC is that, in the latter system, the question of justification is not analysed together with the issue of violation itself, as in the former, but rather only afterwards.

There is another way in which the TBTA strives to facilitate free trade, while at the same time preserving national regulatory autonomy. Namely, the TBTA encourages its members to accept the technical regulations of other members as equivalent (mutual recognition, Art. 2.7). Furthermore, it encourages member states to conclude agreements on mutual recognition of the results of their conformity assessment procedures (Art. 6.3). The European Community "has relied on the TBT Agreement's encouragement of such agreements to extend its mutual recognition activity from the internal sphere (as part of its single market programme) to its trade relations with third countries",99 and has

\footnotetext{
${ }^{95}$ United States - Standards for Reformulated and Conventional Gasoline, WT/DS2/AB/R, 20 May 1996. See Hudec, (n. 82) p. 644

${ }^{96}$ See J. Scott, Mandatory or Imperative Requirements in the EU and the WTO, in C. Barnard and J. Scott (eds), The Law of the Single European Market, Unpacking Premises, (n. 71)

${ }^{97}$ Opinion of Advocate General Jacobs in C-378/98 PreussenElektra AG v. Schleswag AG [2001] ECR I2099

${ }^{98}$ Craig and de Búrca, (n. 46), p. 661

${ }^{99} \mathrm{P}$. Beyon, Community mutual recognition agreements, technical barriers to trade and the WTO's most favoured nation principle, ELRev., 2003, vol. 28, no. 2, p. 233.
} 
concluded several mutual recognition agreements (MRA). However, it is clear that the mutual recognition principle in the WTO has not yet achieved the importance it has in the EU. The mere encouragement of mutual recognition in the WTO does not contribute to trade liberalisation as much as the real requirement of mutual recognition in the EU. The same is true for the MRAs, since "recognising conformity assessment procedures is much less significant than recognising underlying standards". ${ }^{100}$

\subsection{SPS Agreement}

The SPS Agreement is also designed to tackle not only discrimination, but other disguised restrictions on international trade as well. However, such trade liberalisation is to be brought into accord with the protection of life and health.

The first way of reconciling these two aims in the SPSA is by encouraging harmonisation through international standards (Art. 3), such that measures which conform to international standards are deemed necessary for the protection of life or health, and are presumed to be consistent with the SPSA and the GATT ' 94 . However, member states may adopt higher standards under certain conditions.

Secondly, the SPSA introduces a kind of mutual recognition by providing that member states shall accept the SPS measures of other member states as equivalent, even if these measures differ from their own or from those used by other member states trading in the same product, provided that the exporting member state objectively demonstrates to the importing member state that its measures fulfil the latter's appropriate level of SPS protection (Art. 4).

The first case based on the SPSA was Beef Hormones, ${ }^{101}$ and it was a particularly important one in that the Appellate Body applied an obstacle-based approach for the first time, determining that a non-discriminatory measure was in violation of WTO obligations.

In this case, the Appellate Body, unlike the Panel, found the EC's ban on the importation of meat and meat products from cattle treated with six specified growth hormones to be in accordance with Art. 5.5 SPSA. The Appellate Body read Art. 5.5 in the context of Art. 2.3, examining three conditions which had to be cumulatively met in order for Art. 5.5 to be breached. The existence of the first element was clear: the EC had adopted its own appropriate levels of sanitary protection. The Appellate Body considered that the second condition, i.e. that the levels of protection exhibited arbitrary or unjustifiable distinctions (concerning differentiation between hormones used for growth promotion and carbadox and olaquindox), had also been met. However, the AB found that the third element was not present, i.e. that these different levels of protection did not

${ }^{100}$ K. Nikolaïdis, Non-Discriminatory Mutual Recognition: An Oxymoron in the New WTO Lexicon?, in T. Cottier and P. C. Mavroidis, eds., P. Blatter, associate ed., Regulatory Barriers and the Principle of Nondiscrimination in World Trade Law, University of Michigan Press, Ann Arbor, 2000, p. 270.

101 EC Measures Concerning Meat and Meat Products (Hormones), Report of the Appellate Body, WT/DS26/AB/R, WT/DS48/AB/R of 16 January 1998 
"result in discrimination or a disguised restriction on international trade". ${ }^{102}$ The EC measure was judged to be non-discriminatory.

Nevertheless, the Appellate Body found that Arts. 5.1. and 3.3 SPSA had been breached, because the measure was not based on a risk assessment within the meaning of Art. 5.1 and 5.2 SPSA. Consequently, in Beef Hormones, the Appellate Body held a nondiscriminatory measure to be in breach of the SPSA.

The Hormones case was, therefore, a step beyond the conventional conservative view of trade liberalisation that applies a discrimination test in the area of market regulation (supra), because, as Weiler puts it, "[t]he Hormones case... did not essentially turn on denial of national treatment, but on a Dassonville-like complaint that a nondiscriminatory measure to trade was not justified". ${ }^{103}$

Considering the interpretation of the SPSA given by the Appellate Body in Beef Hormones, I agree with Scott that the SPS Agreement "rests upon an expanded conception of the 'basic rule', taking us beyond a discrimination based approach to international trade, and upon a restrictive interpretation of the exceptions to the rule" (being territorially restrictive and epistemologically closed in privileging scientific rationality). ${ }^{104}$ In consequence, it is possible that the WTO will soon face a development similar to that of the EC following Dassonville, but hopefully will be able to avoid its flaws.

\section{CONCLUDING REMARKS - SPECULATING ON POSSIBLE APPROACHES}

In my understanding of the ECJ's case law on the free movement of goods, following Cassis and Sunday Trading it has primarily aimed at limiting and defining the scope of Article 28. Krantz and Keck attest to this. However, in several more recent cases in other areas of free movement, the ECJ has extended the scope of the relevant Treaty articles more widely than ever before, thus raising doubts as to whether the ECJ actually intends to limit the scope of Art. 28. These cases are relevant in the context of the free movement of goods because there are indications that case law is moving towards a uniform approach to all fundamental freedoms. ${ }^{105}$ One such case in which the ECJ extended the reach of a Treaty article was Carpenter. ${ }^{106}$ Here it was determined that Art. $49 \mathrm{EC}$ on the free movement of services had been breached by a measure that was merely "detrimental" to the conditions under which a fundamental freedom is exercised. A similarly broad understanding of the Treaty may be found in recent case law on the free movement of capital, where the ECJ has extended Article 56 to cover measures deterring

\footnotetext{
${ }^{102}$ Appellate Body report, para. 246

${ }^{103}$ Weiler, (n. 4), p. 3

${ }^{104}$ J. Scott, (n. 72), p. 159

105 See Gebhard, (n. 3), para. 37, opinion of Advocate General Elmer in C-189/95 Criminal proceedings against Franzén [1997] ECR I-05909, para 62.

${ }^{106}$ C-60/00 Carpenter $v$ Secretary of State for the Home Department [2002] ECR I-6279
} 
or dissuading the exercise of this fundamental freedom. ${ }^{107}$ In my opinion, these measures are exactly the kind which the Krantz test of "too uncertain and indirect" effect should exclude from the scope of the Treaty. It is worth mentioning here that the Kranz formula has already been applied outside the area of goods (e.g. Graf $f^{108}$ for the free movement of workers, Semeraro ${ }^{109}$ for the freedom of establishment). The following analysis of an optimal approach to the free movement of goods may perhaps also be applicable to other fundamental freedoms.

An optimal approach to Article 28 EC needs to precisely define and delimit the scope of the Article so that it would not catch all obstacles to trade. ${ }^{110}$ This approach could be built upon the tests that the ECJ developed in both Krantz and in the Keck line of case law.

The Keck line of case law is useful in constructing an optimal approach because it contains two important criteria: one on discrimination, and the other on market access. However, as discussed above, the reach of Keck is limited due to the unclear concept of "certain selling arrangements".

Krantz supplements Keck by excluding from the scope of Article 28 those measures that Keck cannot exclude, as they are not rules on "certain selling arrangements", although they have the same effect. Another reason why I consider Krantz to be important is that its formula of "too uncertain and indirect effect" enables better balancing of the values at stake. This is particularly significant with regard to the market access criterion, since an optimal approach must define what kind of effect on market access is to be considered a breach of the Article. Namely, should only measures completely barring market access be prohibited or, on the contrary, should Article 28 already be triggered if market access is merely hindered? The best solution probably lies somewhere in between these two options, and can be determined via a Krantz-type proportionality assessment. In my opinion, it is certainly necessary to include measures that completely bar market access within the scope of Art. 28, but certain other measures that only impede it should also be prohibited. Conversely, I think that measures which merely hinder market access have a "too uncertain and indirect" effect on trade and, therefore, should be placed outside the scope of Article 28.

Certainly, proportionality is not a clear and precise term, and it could be difficult to apply it in practice. It is, moreover, probable that a different standard of proportionality would be adopted by different national courts. However, it would be for the ECJ to set the conditions or guidelines for determining whether a measure impeding market access

${ }^{107}$ C-483/99 Commission v. France [2002] ECR I-4781, C-503/99 Commission v. Belgium [2002] ECR I4809, C-98/01 Commission v. United Kingdom, judgement of 13 May 2003

${ }^{108}$ C-190/98 Volker Graf v Filzmoser Maschinenbau GmbH [2000] ECR I-493

${ }^{109}$ C-418/93 Semeraro Casa Uno Srl v Sindaco del Commune di Erbusco, joined cases, etc. [1996] ECR I2975

${ }^{110}$ The need for Article 28 to catch all obstacles to trade was certainly removed with the establishment of the single market. As Weiler points out, many things had already changed in the EC by then. There was a commitment by national administrations to the single market, and protectionism was not as frequent as it once was, so that the new approach to Art. 28 had to be more tolerant towards national regulatory diversity, as was also the case with the harmonisation programme. Weiler, (n. 4), p.226/227. 
is proportionate. Here another question arises: "Proportionate to what?" There are several possible solutions to this.

The first solution would be to merge analysis of the issue of violation itself with that of regulatory justification. This would mean that a measure affecting market access must be proportionate to a legitimate aim (such as environmental or consumer protection). In other words, the question as to whether a measure is caught by Art. 28 would be decided along with its justification. It is noteworthy that this approach resembles the "aim and effects" test under Art. III GATT, which also considers the issue of regulatory justification together with the violation itself. However, the purpose of such an approach in the WTO is to enable member states to justify indistinctly applicable measures which could otherwise not be justified. In contrast, this is not necessary in the EU, as this is achieved through mandatory requirements. Furthermore, this approach would not tackle the main problems that the ECJ has been trying to solve for decades. One of the reasons why the ECJ has tried to restrict the scope to Art. 28 is precisely to avoid a situation in which national courts or the ECJ itself have to enter into possible justifications of measures in each case where there is an obstacle to trade.

The second solution is to say that a measure does not have to be proportionate to a value, but rather correspond to the fact that there is a lack of harmonisation, and that an obstacle at stake exists solely because different MS have different rules. As M. P. Maduro points out (see below), this solution solves the problem of the additional burden that often occurs due solely to legislative disparities between MS. Since the concept of dual burden is associated with discrimination, the difference between discrimination and lack of harmonisation becomes trivial. This solution is actually a de minimis test, and one of the problems with such an approach is that the ECJ has already expressly excluded a de minimis test for Art. 28. ${ }^{111}$

This kind of de minimis test in respect of market access was developed by AG Jacobs in Leclerc, ${ }^{112}$ and has been advocated more recently by C. Barnard. ${ }^{113}$ Barnard supports the approach to non-discriminatory measures (in the area of goods and persons) defined by "prevention or direct and substantial hindrance of access to the market". ${ }^{114}$ This kind of proportionality assessment would also represent a de minimis rule for the use of Article 28. Further, Barnard contends that there is actually no need for a separate criterion of discrimination, since measures which discriminate necessarily also substantially hinder market access.

Weiler proposes two rules for bringing measures within the scope of the Treaty. The general rule should provide that "national provisions which do not affect in the same manner, in law or in fact, the marketing of domestic products and of those from other Member States, must be justified by a public interest taking precedence over the free

${ }^{111}$ Van de Haar and Kaveka de Meern BV, supra (n. 40)

${ }^{112}$ Opinion of Advocate General Jacobs in Leclerc-Siplec (n. 62), para. 49

113 C. Barnard, The Substantive Law of the EU - The Four Freedoms, Oxford University Press, Oxford, 2004 and Barnard in op. cit. (n. 37)

${ }^{114}$ Barnard (n. 113), p. 144-148 
movement of goods". ${ }^{115}$ This is a principle of non-discrimination which Weiler considers to be a general principle of Community law. If compared to the GATT, it would then be a national treatment principle equally applicable in both the pecuniary and non-pecuniary areas. The special rule for free movement should be that "national provisions which prevent access to the market of imported products must also be justified". ${ }^{116}$ This would catch non-discriminatory measures that could totally exclude a good from the market.

Similarly, Maduro ${ }^{117}$ argues that the case law of different free movement rules relating to non-discriminatory provisions could be reconciled via two tests. ${ }^{118}$ The first test is whether a measure imposes an additional burden on products (or services, or nationals) from other Member States, while the second test concerns market access. Regarding this, Maduro, building upon Weiler, argues that hindering market access should not be sufficient for a measure to fall within the scope of the Treaty, such that only those measures which bar market access in law or in fact would be caught by it.

Maduro's analysis points out the problems with both tests. The problem with the first test is that an additional burden often occurs for the sole reason that Member States have different rules. Furthermore, since the concept of dual burden is associated with discrimination, the difference between discrimination and lack of harmonisation becomes trivial. The second test includes absolute bans and measures which do not authorise the national market entry of products exactly as they were produced in their market of origin. This component of the test brings it close to a double burden test, and to the problems discussed in connection therewith. "In the end, underlying the double burden or market access tests is a suspicion that national measures of that type are discriminatory since they will impose an additional cost on imported products. But such a broad notion of discrimination ends up coinciding with the problem of legislative disparities. The question becomes whether the Court of Justice should review all non-harmonised national regulations?"119 This problem could also be handled if the ECJ were to develop tools for the application of Krantz-type balancing, as well as for determining exactly what constitutes discrimination.

It is noteworthy that the balancing of free trade with other values at stake appears in every aspect of analyses of alleged European law violations or WTO rules violations. As de Búrca stresses, "this kind of balancing also takes place, albeit in a less explicit or in a more circumscribed way, at the stage of considering whether discrimination or protectionism exists". ${ }^{120}$ Such balancing exists in the context of Art. 28 EC (as exemplified in Walloon Waste, where the Court determined that the measure could differentiate between Walloon and other kinds of waste, since they are not like), as well

\footnotetext{
${ }^{115}$ J. H. H. Weiler, The Constitution of the Common Market Place: Text and Context in the Evolution of the Free Movement of Goods in P. Craig and G. de Búrca (eds.) Evolution of EU Law, Oxford University Press, Oxford, 1999 and Weiler in op. cit. (n. 4), p. 228.

${ }^{116}$ Ibid.

${ }^{117}$ Maduro, (n. 53)

118 This uniform approach would be based on recent case law in the area of goods (e.g. Franzén for the first test and Gourmet for the second).

${ }^{119}$ Maduro, (n. 53)

${ }^{120}$ De Búrca, (n. 71), p. 192
} 
as under Art. $90 \mathrm{EC}$, in determining which products are "similar", and under Art. $25 \mathrm{EC}$, in determining whether a measure is equivalent to a customs duty. ${ }^{121}$

Regarding the approach to the free movement of goods in the WTO, it has already been stated that the WTO is moving beyond the requirement of non-discrimination towards an obstacle-based approach. WTO rules on the free movement of goods are catching many non-protectionist national measures, due to, firstly, the imprecise scope of Art. III GATT regarding PPMs and, secondly, the understanding of the concept of "like products". Finally, the obstacle approach has been adopted by the TBT and SPS Agreements, and confirmed by the Appellate Body in Beef Hormones. The agreements attempt to balance the values at stake and circumvent the dangers of catching too many national measures by promoting mutual recognition and harmonisation, as well as by providing open-ended possibilities of justification.

Some of the problems occurring could be resolved by applying the "aim and effects" test. It is interesting to compare how balancing the interests of free trade and national autonomy would take place in the GATT if it were to completely develop the "aim and effects" test with the situation in the EU. Firstly, in both systems directly discriminatory (protectionist) measures would be prohibited unless justified by a limited set of explicitly stated reasons (Art. 30 EC, Art. XX GATT). Secondly, indistinctly applicable measures causing a dual burden or indirect discrimination in the EU would be caught by Article $28 \mathrm{EC}$, yet could be justified by Art. 30 or mandatory requirements. In the WTO, under the "aim and effects" test, the legitimate objective of such measures would be decided under Art. III GATT simultaneously with the issue of violation. (These legitimate, i.e. non-protectionist objectives would be open-ended, as are mandatory requirements in the EU.) Finally, in the EU indistinctly applicable measures with equal burden that represent completely non-discriminatory obstacles to trade are treated in the same way as the other category of measures, while it remains to be seen what the solution will be in the WTO should it adopt an "obstacle-base approach" in areas other than those of the SPS and TBT Agreements.

There are strong mutual influences between the EU and WTO systems of the free movement of goods. There are certainly some useful lessons to be learned from the development of both, and some principles could perhaps be cross-applied. In defining the scope of Art. III and the TBT and SPS Agreements, it would obviously be useful for the Appellate Body to draw lessons from the ECJ's case law post-Dassonville, while taking into account the differences between the EC and the WTO. In my opinion, in moving beyond discrimination the WTO's rules on the free movement of goods should certainly not become so broad as to catch all obstacles to trade, since even in the EU, which aims at a much higher level of integration than the WTO, Art. 28 does not cover all such obstacles. This precise delimitation of Art. III GATT and the TBT and SPS Agreements would be highly relevant for the EU, since it is a WTO member. In turn, the EU could also have an effect firstly, on trade liberalisation in the WTO, and secondly, on the WTO's regulatory values, and on the creation of mechanisms enabling the protection of interests other than trade.

${ }^{121}$ Ibid. 
Firstly, with regard to the EU's effect on trade liberalisation, it is possible that the internal dynamics of the EU will have a strong external impact, and that it will contribute to the creation of trade barriers within the WTO. Namely, there are obstacles to trade in the EU which cannot be removed by negative integration (primarily Art. 28 EC), but rather require positive integration. Positive integration means the adoption of common rules. "When common rules are negotiated, the government with legitimate, more stringent standards is in a strong bargaining position. So long as there is no agreement, its industry is protected from foreign competition, while those of its trading partners are hurt by being denied access to the market. Consequently, the cost of no-agreement falls more heavily on its trading partners. In such circumstances, a negotiated outcome will be closer to the preferred position of the government with the stricter regulation". ${ }^{122}$ In other words, the dynamics of EU harmonisation create regulatory peaks which form an obstacle to trade within the WTO. These external influences of the internal market should be taken into consideration when deciding on the optimal scope of EC Treaty articles and EC common rules.

Secondly, regarding the WTO's regulatory values and the creation of mechanisms which enable the protection of interests other than trade, Weiler predicts that, although convergence of the WTO and the EU can only be limited, "[i]t will not be long before the WTO Panel and/or Appellate Body will pronounce a WTO version of the doctrine of parallel functionalism (mutual recognition)", one whose legislative expression can already be found in the TBT and SPS Agreements. ${ }^{123}$ It is also likely that we will see more harmonisation in the WTO in the form of "international standards".

${ }^{122}$ A. R. Young, Incidental Fortress: The Single European Market and the World Trade, JCMS, 2004 , vol. 42, no. 2, p. 401, 410.

${ }^{123}$ Weiler, (n. 4), p. 231. 